\title{
The Male Tomcat Fighter as Superior Cadres for Handling Paederus Dermatitis at Daarul Qur'an Islamic Boarding School, Karanganyar, Central Java
}

\author{
M N Lathif ${ }^{1}$, I P Fisabilillah ${ }^{2}$, A S Salma ${ }^{3}$, N Advaita ${ }^{4}$, S L Indriyani ${ }^{1}$, P Dirgahayu ${ }^{5}$, M E Irawanto ${ }^{6}$ \\ ${ }^{1}$ Medical, Faculty of Medicine, Sebelas Maret University, Surakarta \\ ${ }^{2}$ Biology, Faculty of Mathematics and Natural Sciences, Sebelas Maret University, Surakarta \\ ${ }^{3}$ Agrotechnology, Faculty of Agriculture, Sebelas Maret University, Surakarta \\ ${ }^{4}$ Pharmacy, Faculty of Mathematics and Natural Sciences, Sebelas Maret University, Surakarta \\ ${ }^{5}$ Section Parasitology, Faculty of Medicine, Sebelas Maret University, Surakarta \\ ${ }^{6}$ Division of Skin and Sex Health, Faculty of Medicine, Sebelas Maret University, Surakarta
}

\begin{abstract}
Dermatitis venenata caused by Paederin poison called Paederus Dermatitis. This type of dermatitis causes inflammation of the skin with distinctive characteristics such as erythema and pruritus accompanied by vesicles in the cervical region. This type of inflammation generally occurs in high temperature areas with tropical climates. Indonesians generally do not understand the incidence of dermatitis, so the incidence of dermatitis is still high and has not been treated appropriately. Daarul Quran Putra Islamic Boarding School has high incidence in paederus dermatitis so that cadres are formed called Tomcat Fighter as Detective Tomcat to control and overcome the incidence of Paederus Dermatitis. This service aims to determine the success of the Fight Tomcat strategy at the Daarul Qur'an Islamic Boarding School in Karanganyar, Central Java. 10 male students given the treatment of education. In the data there was an increase in recovery from 82 sufferers becoming fully recovered. The conclusion is the education we gave to male cadres proves the success of Fight Tomcat strategy to recover the suffered students.
\end{abstract}

Keywords: Dermatitis Paederus, Incidence, Superior Cadres

\section{INTRODUCTION}

Islamic Boarding Schools known as Daarul Qur'an Karanganyar Islamic Boarding School are inhabited by students who study the science of Islam. Daarul Qur'an education is an equivalent junior high school education. This modern boarding school is located in Sanggir, Paulan, Colomadu, Karanganyar Regency, Central Java Province. The residents of the lodge consist of 180 male students and 175 female students aged 13-15 years, classified as teenagers who complain of hot wounds and elongated skin. The wound leads to dermatitis venenata caused by Paederin poison called Dermatitis Paederus or skin inflammation caused by tomcat. Santri did not understand the importance of closing the door of the room at night because the hot air caused the door to continue to be opened, the behavior of maintaining cleanliness was still low, and using bright lights while sleeping. Where the behavior of the cottage community is increasingly attractive tomcat to enter the boarding school area. This type of dermatitis causes inflammation of the skin with distinctive characteristics such as erythema and pruritus accompanied by vesicles. These 
lesions will turn dark or infected after 24-48 hours (Caceres, 2017; Nasir et al., 2015).

Paederus littoralis is located in rice fields with warm temperatures. Paederus littoralis is the main group of leafed animals (Arthropods) which belong to the large family of beetles (Staphylinidae). This beetle has a relatively slim body with a width of $1.5 \mathrm{~mm}$ and a length of 7-10 mm. Paederus littoralis can be found in almost all parts of the world, especially in warm tropical countries such as Indonesia, Malaysia and India. This is because Paederus littoralis can survive better in warmer climates than in cold climates (Bhatti, 2018; and Bong et al., 2015).

The santri boarding schools tend to not know how to handle tomcat properly. Direct contact between tomcat and the skin can cause itching accompanied by a burning sensation caused by the poison Paederin it causes. This infection due to tomcat can be transmitted through social contact with the santri. Mass housing conditions such as Islamic boarding schools will be the most frequent place to transmit tomcat massively. This of course will greatly interfere with teaching and learning activities, worship activities, and other daily activities.

Based on the above problems, it is necessary to have the initiation of The Male Tomcat Fighter as Superior Cadres in an effort to increase the knowledge of the boarding school residents. The activity was carried out at Daarul Quran Pesantren Karanganyar, Central Java as a prototype with the target of the residents of the cottage in order to provide the first prevention in handling tomcat. In the implementation of the activity an approach of fun integrated controlling program was carried out which was a specially designed approach to support the prevention process relating to the healing of santri and knowledge related to tomcat which was well structured and taught with a gradual and step-by-step activity pattern.

\section{METHOD}

\section{A. Preparation}

Preparation is the initial stage before carrying out activities. In this stage several activities are carried out, among others

\section{Survey and preparation}

A survey was conducted to identify problems that existed at the Daarul Qur'an Islamic Boarding School in Karanganyar, Central Java. Then a partnership agreement with the relevant village apparatus is carried out.

\section{Internal discussion}

Discussion related to the implementation of activities and timeline, operational activities, and division of tasks of each member by the community service team to fight Tomcat.

\section{Tools preparation}

Preparation of tools and supporting materials needed for the implementation of activities.

\section{Implementation of Activities}

The activity was held at the Daarul Quran Islamic Boarding School in Karanganyar, Central Java. Program implementation uses the approach of the fun integrated controlling program. Fun integrated controlling program is a controlling approach specifically designed to prevent the spread of tomcat in mass in ponpes with a fun program. This system is an approach method with reference to information from several literature as community medical practices such as the Ministry of Health of the Republic of Indonesia, which is then assembled into a mini curriculum. This curriculum is tailored to the standard needs to teach directly (cognitive), practiced directly (affective-psychomotor). The activities carried out included socialization, material training, direct practice, monitoring, and evaluation.

\section{a. Socialization}

The socialization was given to The Male Tomcat Fighter regarding the Fight Tomcat program at the Daarul Quran Karanganyar 
Islamic Boarding School by providing an explanation of the intent and purpose of the activities carried out. The dedication team showed about the facts of the problem in the case of misunderstandings that occurred in the Islamic boarding school and the dangers resulting from medication errors.

\section{b. Training}

The training was conducted by teaching the program to fight tomcat directly to the students of the sons and daughters of the Daarul Qur'an Karanganyar Islamic Boarding School conducted by the service team. In the tomcat fight program, it contains material about guidance on how to control tomcat correctly and precisely, good prevention material in the family, and development of activities to support it as a cadre fight tomcat. Each meeting is limited to 1 material discussion for approximately 1 hour.

\section{c. Monitoring}

Monitoring is carried out by the service team to monitor the extent of participants' understanding of the material provided by providing guidance books to students. The service team conducted a question and answer session with the santri with the individual approach of the participants in the fight tomcat program.

\section{d. Evaluation}

The program evaluation was carried out by the service team to the participants of the Fight Tomcat program by giving pretest and posttest. The results of the pretest and post-test compared to whether there was a change after the material was given by the team. There is a pretest and post-test as an evaluation material to see the understanding of the cadres on the material presented. The hope is that more than $90 \%$ of participants can understand the material that has been delivered.

\section{RESULT AND DISCUSSION}

In the cadre management, Moh Iqbal Hanafi as cadre chairman, vice cadre, namely
Zulfan Rasyid R, secretary namely M. Rangga ARCP, treasurer entrusted to M. Hafiizh Dimas S., community coordinator namely Fawaz Fikri, coordinator of examination Ahmad Arafat Al Mubarok, alumni coordinator and partner Alfin Murzaeni, hygiene coordinator $\mathrm{M}$. Tegar Aji D, drug coordinator Hanif Mahardika Nugroho, and documentation coordinator Ghiyyats Azzumar Ghufron.

Our cadre activities are grouped into 2 namely counseling and training. Extension activities are divided into Tomcat Screening Action, Tomcat Challenge Reorientation and Understanding, Good Bye Tomcat, and Tomcat Screening Activities 2. While Tomcat training activities are Challenge Reorientation and Understanding, Just Do it, Socialization and Training from the Health Office. The extension activities are as follows:

\section{A. Tomcat Screening Action}

This activity is carried out by filling out questionnaires by cadres which have been provided as pre test scores. The results obtained from the evaluation of the pre-test of the santri experiencing paederus dermatitis. Screening is done by calling two skin and sex specialists. Data from a number of santri were positive for paederus dermatitis.

\section{B. Tomcat Challenge Reorientation and Understanding}

Interactive presentations and discussions between santri and Fight Tomcat Team. This activity is carried out by utilizing power point media, leaflets, and posters. The students understand about tomcat and its habitat and the dermatitis it causes, including the causes, clinical manifestations, complications, management of therapy and prevention of disease.

\section{Good Bye Tomcat}

Giving therapy by skin and sex specialists, and counseling, information, education (IEC) on the right and effective treatment methods. In this activity, topical drugs were also 
distributed, namely Mometasone furoate $0.1 \%$ $5 \mathrm{~g}$ and Betamethasone valerate to treat venenata dermatitis caused by tomcat (Paederus littoralis) or what is called paederus dermatitis. Santri knows how to use drugs effectively and precisely. Santri recovered and were free from paederus dermatitis.

\section{Tomcat Screening 2 Activities}

All male and female students filled out a questionnaire that had been provided as a post test evaluation. The results of the post test were $100 \%$ of students who understood the education provided.

The training activities are as follows:

\section{Tomcat Challenge Reorientation and Understanding}

The students were invited to play Tomcat Ladder (a type of snake ladder), flashcard, and play card box role as a medium of educational training about tomcat and its habitat and dermatitis due to tomcat. The santri can practice and explain about tomcat and its habitat and the dermatitis it causes, including the causes, clinical manifestations, complications, management of therapy and prevention of disease.

\section{Just do it!}

The team and the santri along with the ustadz worked together to install various fittings such as installing LED lights outside the hut and installing nets at each ventilation room. The santri can practice ways to prevent tomcat attacks so that tomcat does not enter the territory of the boarding school.

3. Socialization and Training from the Health Office

Inviting representatives of the Karanganyar District Health Office, Head of the Boarding School Foundation, representatives of Colomadu 1 Health Center, Director of Operational Islamic Boarding Schools, Dermatology Specialists, representatives of the UNS FK BEM, representatives of LKMI, Kesuma Representatives. Collaboration between Daarul Qur'an Karanganyar Islamic
Boarding School and Karanganyar District Health Office and Colomadu Health Center 1. In addition, 10 Detective cadres were inaugurated as a model for the Daarul Qur'an Karanganyar Islamic Boarding School for other lodges in overcoming tomcat.

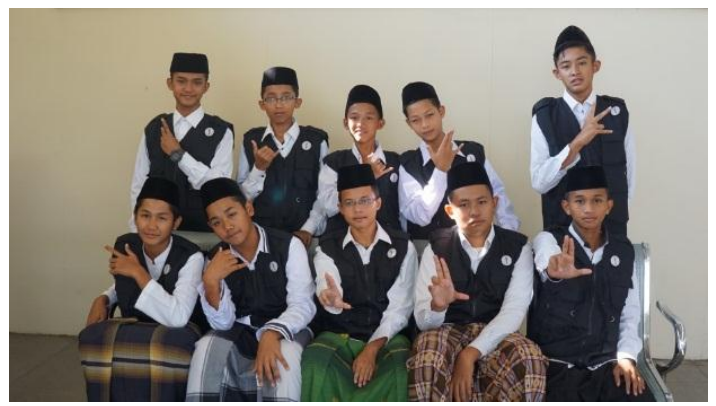

Figure 1. The Male Tomcat Fighter as Superior Cadres

\section{Pre Test The Male Tomcat Fighter as Superior Cadres}

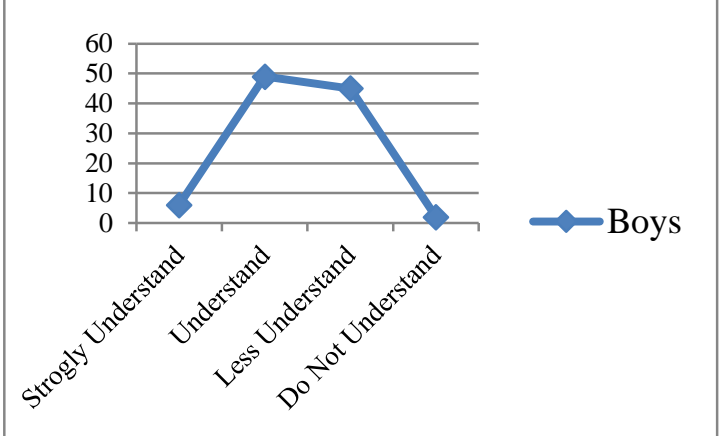

Chart 1. Pre Test The Male Tomcat Fighter as Superior Cadres

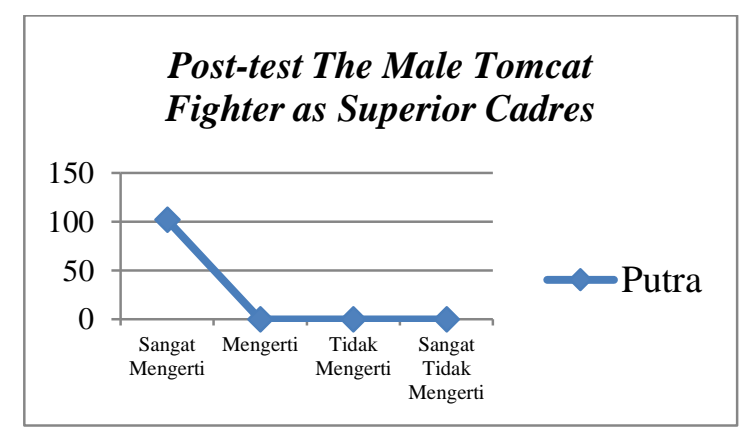

Chart 2. Post-test The Male Tomcat Fighter as Superior Cadres

From the results of Graphs 1 and 2, there is an increase in public knowledge from the value of the pre-test and post-test. The level of one's knowledge is influenced by several factors including education, experience and facilities. With training or education, someone 
will tend to get information, both from other people and the mass media. The more information entered the more knowledge gained about health.

\section{CONCLUSION}

The results of the initial level of knowledge of The Male Tomcat Fighter as Superior Cadres against tomcat are still low and have increased after training was given with the method of the fun integrated controlling program.

\section{ACKNOWLEDGMENT}

On this occasion the author expressed his gratitude to the Medical Faculty of Sebelas Maret University and KEMENRISTEK DIKTI for providing moral and material support to carry out this service activity, so that it could run smoothly.

\section{REFERENCES}

[1] A. A. Bhatti, Khajuria, M. Karyotypic and Morphometric, "Analysis of A Predatory Rove Beetle, Paederus littoralis (Coleoptera: Staphylinidae) from Jammu Region of Outer Himalayas", India. Biosciences Biotechnology Research Asia, 15(2), 2018.

[2] L. J. Bong, K. B. Neoh, Z. Jaal, and C. Y. Lee, "Paederus outbreaks in human settings: a review of current knowledge. Journal of medical entomology", 52(4), pp. 517-526, 2015.

[3] L. Caceres, J. A. Suarez, C. Jackman, A. Galbster, R. Miranda, I. Murgas, J. Pascale, N. Sosa, and A. J. Rodriguez-Morales, "Dermatitis due to Paederus colombinus: Report of an Epidemic Outbreak of 68 Cases in the Province of Darien", Panama. Cureus, 9(4), 2017.

[4] S. Nasir, W. Akram, R. R. Khan, M. Arshad, and I. Nasir, Paederus beetles: the agent of human dermatitis. Journal of Venomous Animals and Toxins including Tropical Diseases", 21(1), p. 5, 2015.

[5] E. Uzunoglu, I.D. Oguz, B. Kir, and C. Akdemir, "Clinical and epidemiological features of Paederus dermatitis among nut farm workers in Turkey. The American journal of tropical medicine and hygiene", 96(2), pp. 483-487, 2017. 